\title{
ELECTRIC VEHICLE, WHY SPAIN?
}

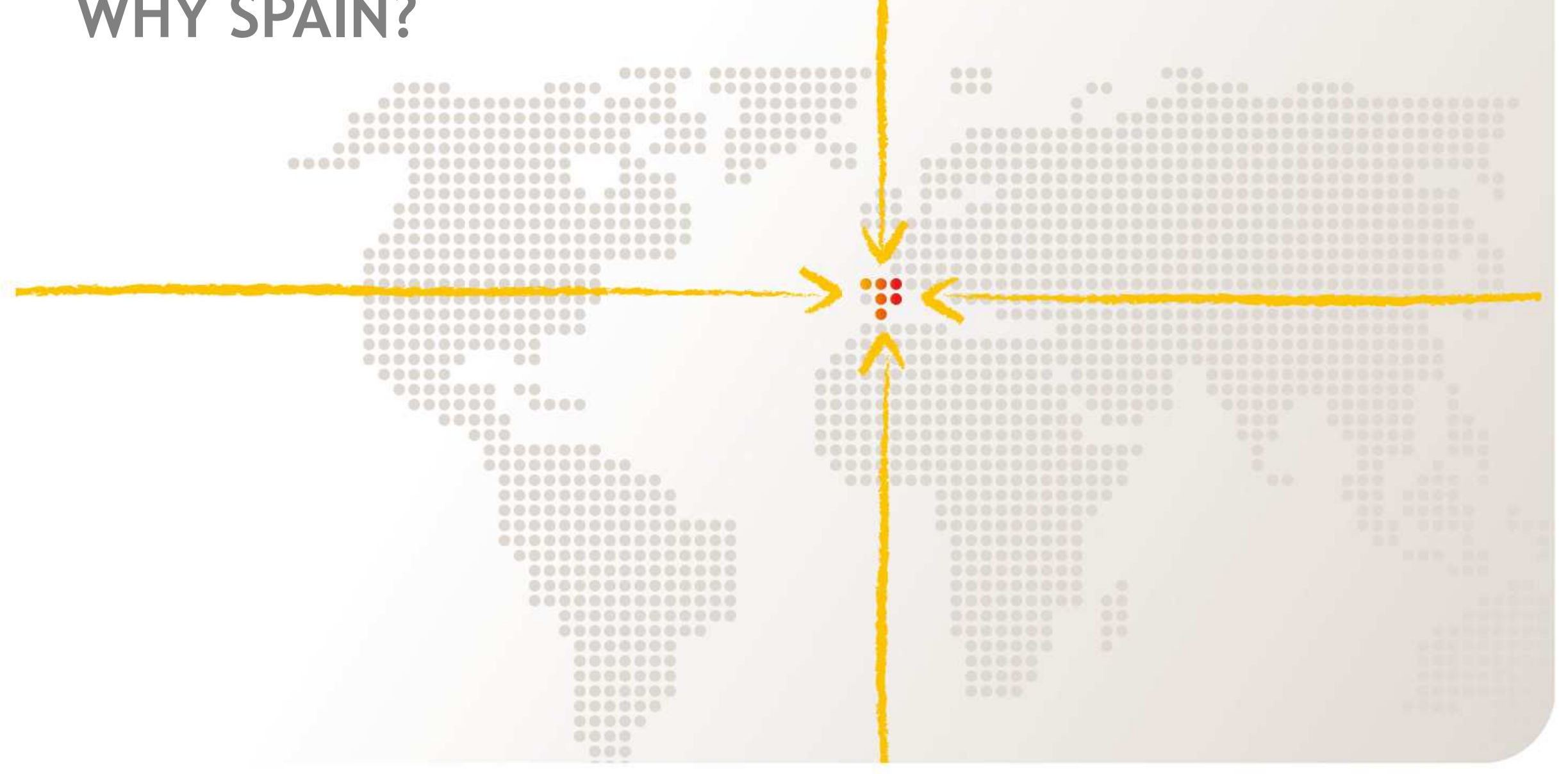

INVEST IN SPAIN

February 2012

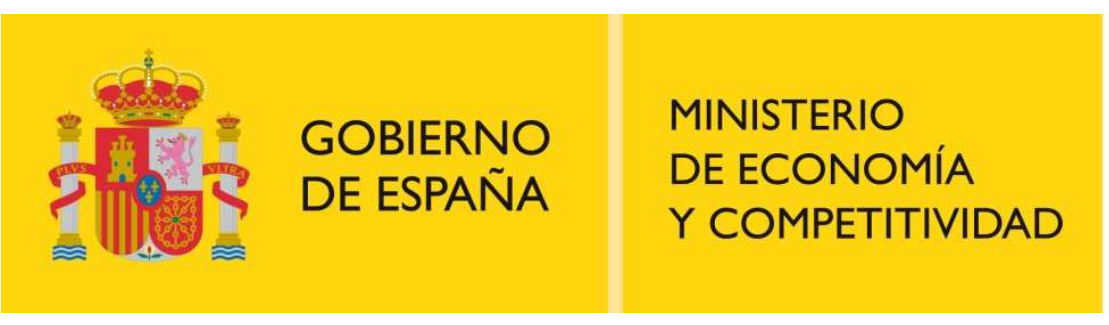

INVESTIN SPAIN

MINISTERIO

DE ECONOMIA

COMPETITIVIDAD 


\section{Index}

\section{Electric Vehicle, why Spain?}

I. Introduction

II. Business Identification

III. Excellent environment

IV. Business Analysis

V. State Aid

VI. Integral Plan for Electric Vehicles (Ministry of Industry)

VII. Project Movele (IDAE)

VIII. Spanish Electric Vehicle Forum (FOREVE)

IX. Project CENIT VERDE

X. Green eMotion (European Comission)

XI. Cooperation and Leadership Opportunities

XII. Conclusions 


\section{Introduction}

The Government of Spain keeps the bet on the electric vehicle. The policy of development of the electric vehicles is one of the priorities of the Ministry of Industry, Energy and Tourism. This kind of vehicle will be a reference in the Sustainable Economy, and an example of a new model of growth for the Spanish economy.

Their combination of energy and environmental efficiency make electric vehicles the clearest example of the move towards a more sustainable and rational mode of transport deemed necessary and desirable by today's societies.

Spain is especially well placed to meet all the technical and business needs of this sector, coupled with the political will to socially consolidate the use of electric vehicles. 


\section{Introduction}

Various initiatives arise from the intention to win for the Spanish industry the projects which are coming up in this field, as well inside as outside our borders:

$\checkmark$ 2011: Granting of 168,5 million Euros for the implementation and development of the electric vehicle. Line of guarantees of $\mathbf{5 0 0}$ million Euros for the development and industrialization of the EV.

$\checkmark$ 2011: Within the framework of the general call of support to strategic industrial sectors the Automotive sector will be protagonist with a specific call of $\mathbf{2 1 5}$ million Euros. The projects related with the hybrid and electric vehicles have special preference.

$\checkmark$ The Project Verde, through the Centre for the Development of Industrial Technology (CDTI), expects to help the proposals for the development in Spain of the technology and manufacturing of the electric vehicle.

$\checkmark$ FOREVE, a forum which brings together important companies whose target is to promote in Spain the development and use of this kind of propulsion.

$\checkmark$ Integral Plan for the Electric Vehicle in Spain. 


\section{Business Identification}

\section{Business Definition}

Although sales in Spain cannot yet be defined as high, the gradual electrification of the motor vehicles in use is an inevitable reality.

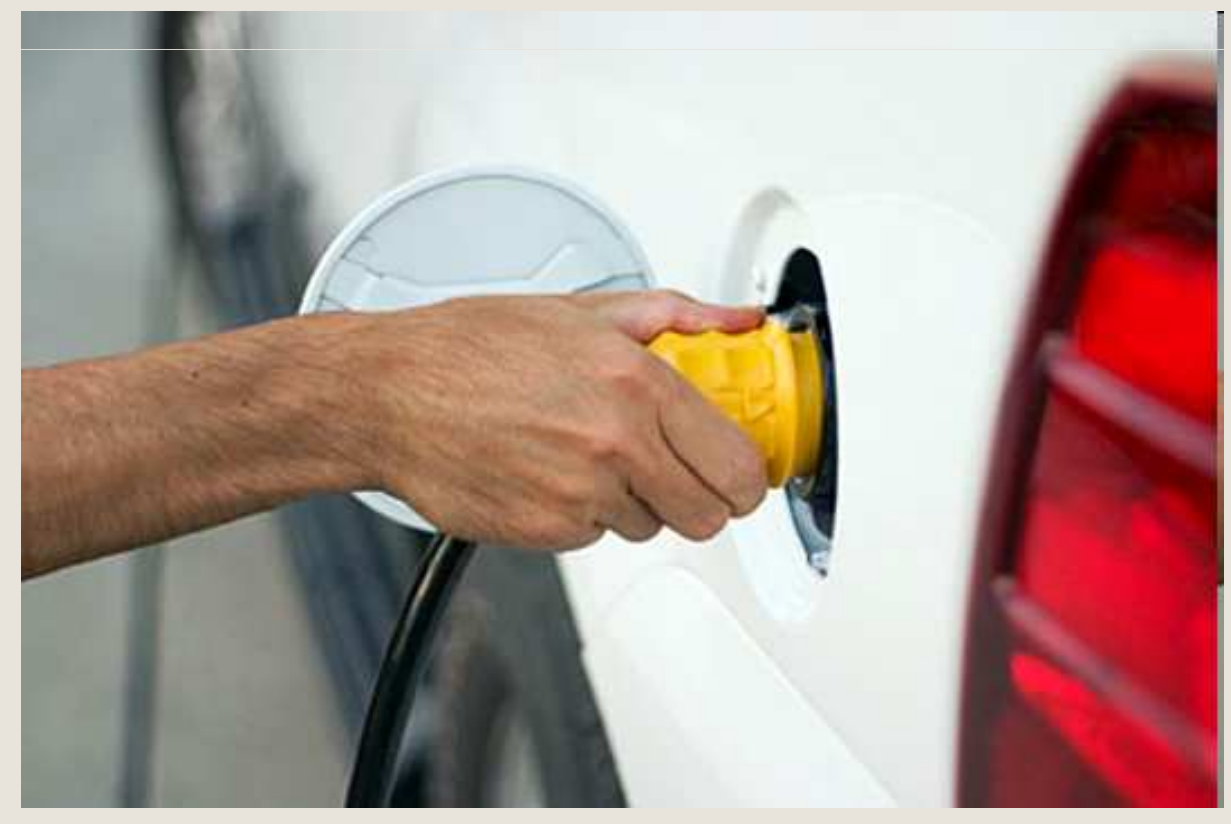




\section{Business Identification}

\section{Value Chain}

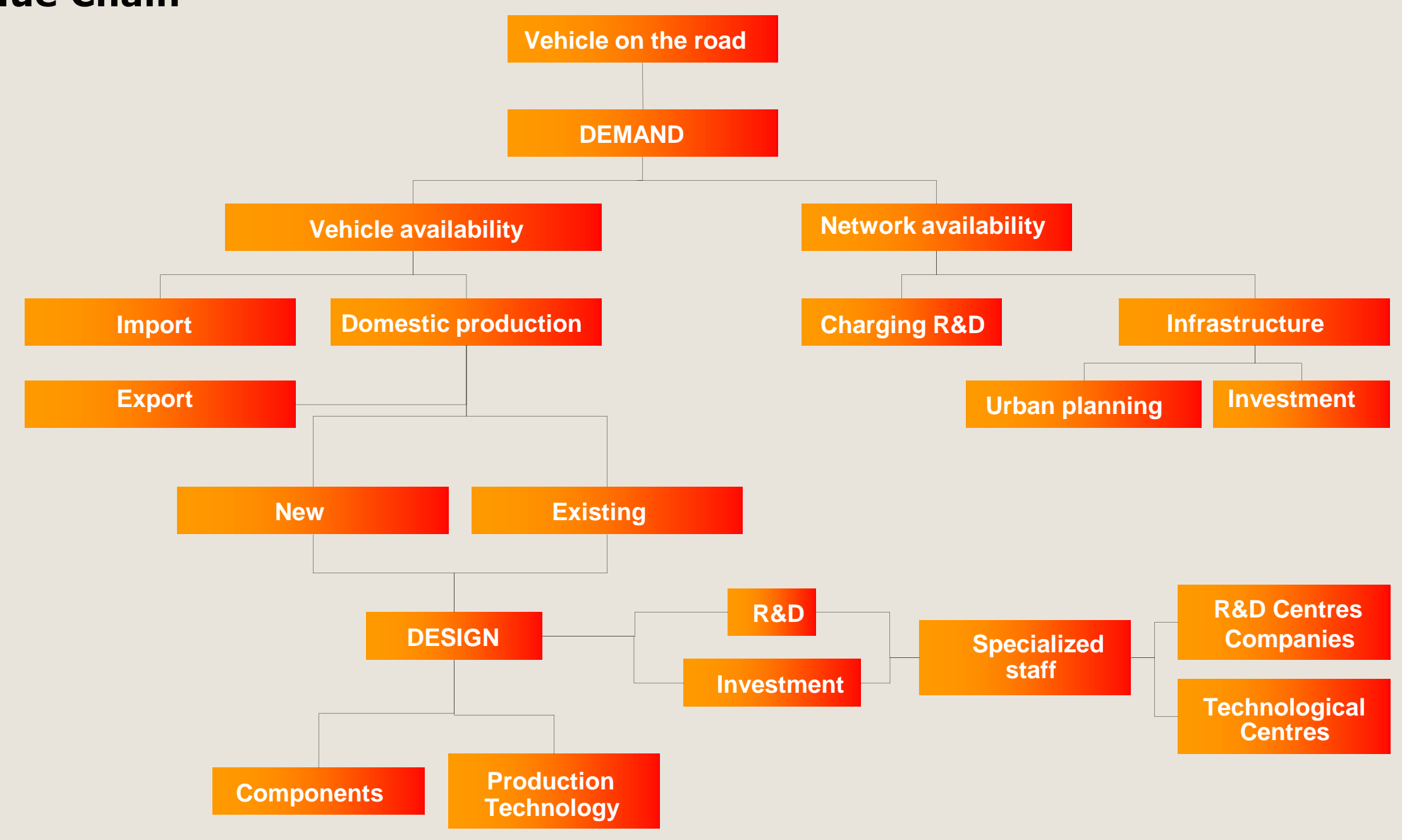




\section{Business Identification}

\section{Description of the Technology}

\begin{tabular}{|l|l|}
\hline $\begin{array}{l}\text { Hybrid Vehicle } \\
\text { (HV) }\end{array}$ & $\begin{array}{l}\text { Combining a thermal engine of medium/big size } \\
\text { with an electric motor as support when moving } \\
\text { off and accelerating. The vehicle is able to work } \\
\text { indistinctly with one, with the other, or with } \\
\text { both at the same time. }\end{array}$ \\
\hline $\begin{array}{l}\text { Plug-in Hybrid } \\
\text { (PEhicle }\end{array}$ & $\begin{array}{l}\text { Vehicles powered exclusively by electric motors, } \\
\text { and whose batteries are charged from the } \\
\text { network or using a small internal combustion } \\
\text { engine which spins constantly. }\end{array}$ \\
\hline $\begin{array}{l}\text { Vehicle with fuel } \\
\text { Cells }\end{array}$ & $\begin{array}{l}\text { Vehicle with an electric motor whose energy is } \\
\text { provided by a chemical reaction inside a fuel } \\
\text { cell. }\end{array}$ \\
\hline $\begin{array}{l}\text { Pure Electric Vehicle } \\
\text { (EV) }\end{array}$ & $\begin{array}{l}\text { Driven exclusively by one or several electric } \\
\text { motors. The charging of the batteries is done } \\
\text { from the network or the batteries are being } \\
\text { replaced. }\end{array}$ \\
\hline
\end{tabular}




\section{Excellent environment}

The characteristics of the Spanish vehicle production, specialized in low range and with models similar to the electric proposals, make it more compatible as in other countries.

In favor of Spain acts the fact to be specialized in medium and low ranges, precisely where the electric cars are included.

Excellent geostrategic situation of Spain, with direct, fast and economic access to:

$\checkmark$ The other main European automobile markets (Germany, France, Italy and United Kingdom)

$\checkmark$ The new emerging markets in North Africa. 


\section{Excellent environment}

The high development in Spain of the wind energy makes our country an ideal destination for the introduction of the electric vehicle on a large scale.

If the electric vehicle is charged during the night, it is possible to use much better the wind energy produced in night hours (off-peak hours).

(Sometimes the wind generators have to be disconnected during the night, as there is not enough demand of electricity.)

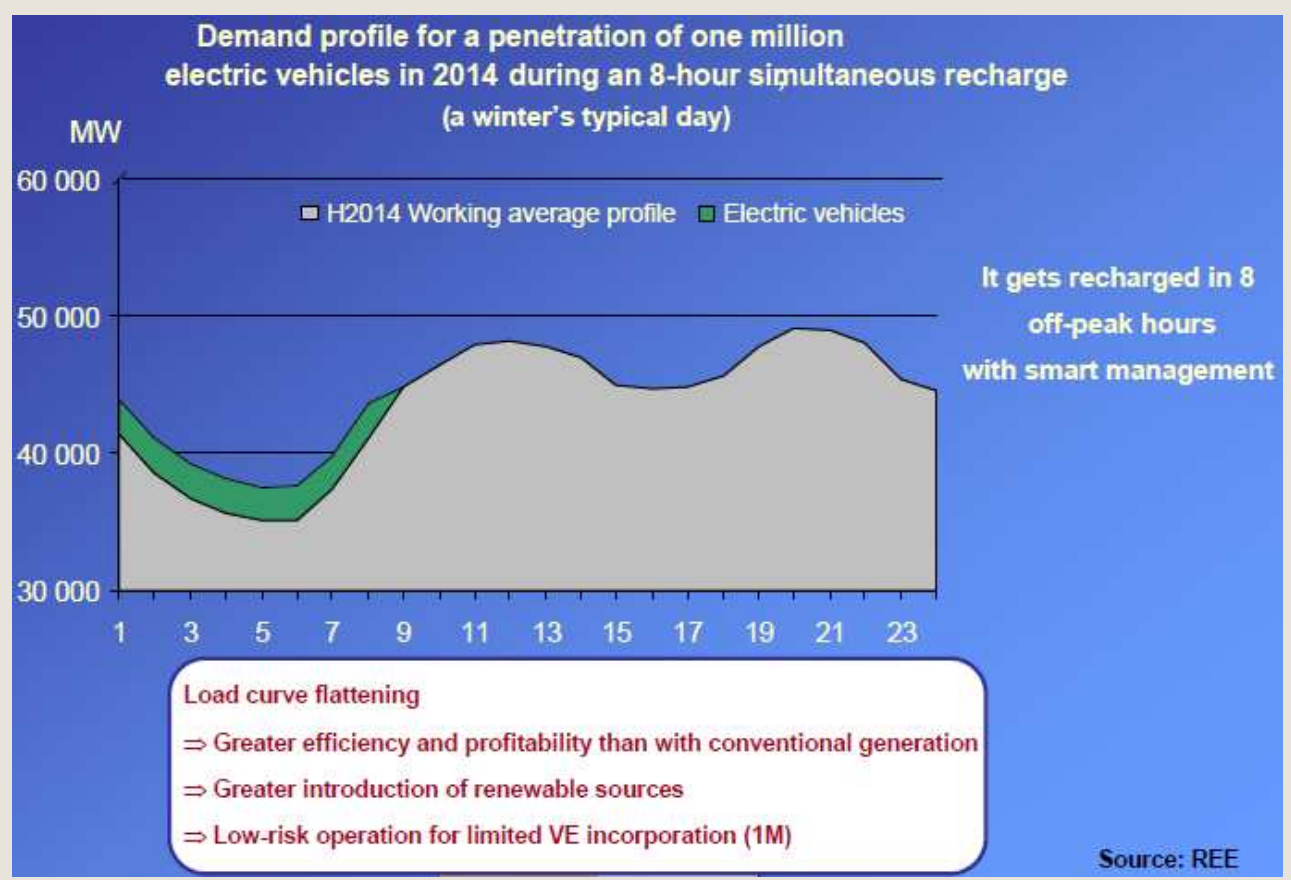




\section{Excellent environment}

Spain has an extensive experience in the automotive sector, as well related to vehicle production, as to having an important sector of automotive parts and accessories.

Our vehicle production plants are between the most competitive at European and world level, and at the same time they have shown that they are very flexible, what entitles them to adapt fast to new market niches.

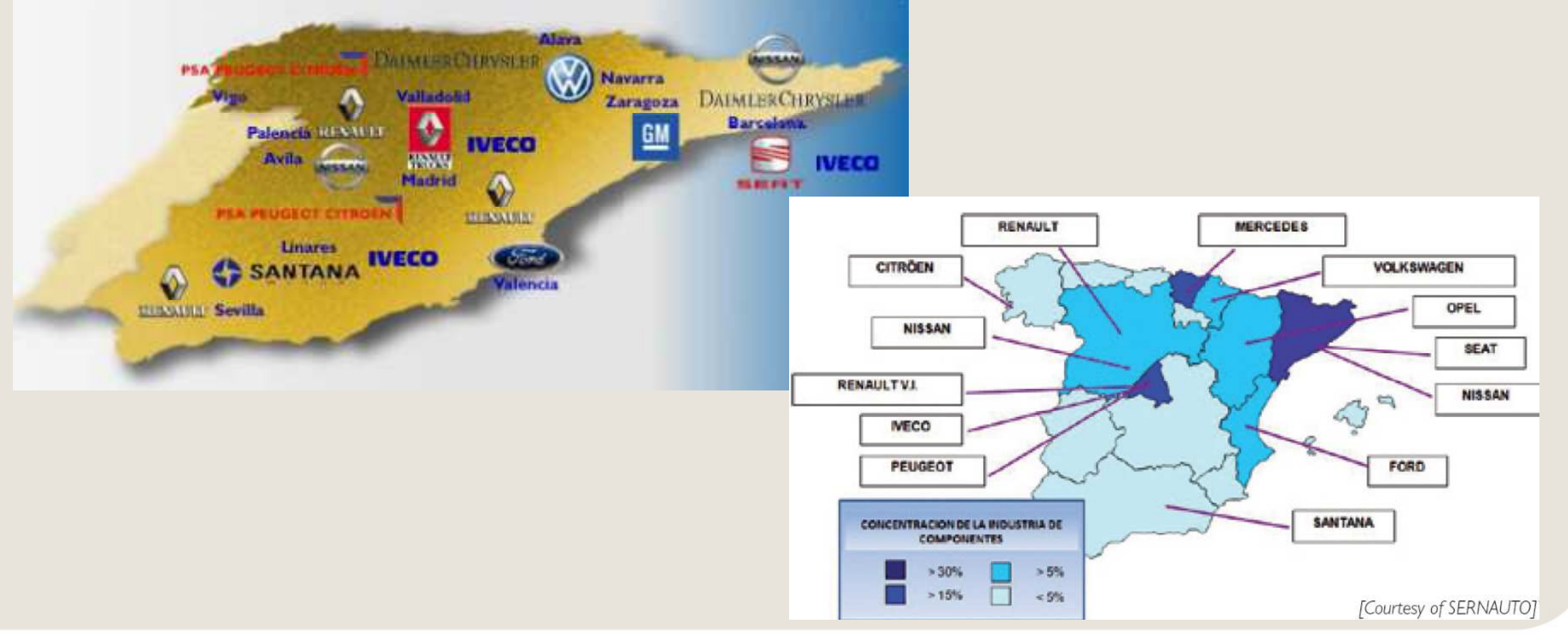




\section{Excellent environment}

\section{Final manufacturing cost is lower}

In many plants in countries with higher labor costs than in Spain, the labor cost is twice as much as in Spain.

$\checkmark$ The transport of a vehicle from a Spanish plant to central Europe can be $60 \%$ of the distance from a plant in Romania, or $45 \%$ of the distance from a plant in Turkey or in Ukraine.

$\checkmark$ The final manufacturing costs in plants in East Europe are above the ones in our plants. That's why the labor cost is a absolutely irrelevant measure. Training, employee turnover, inflexibility, difficulty for outsourcing, stocks, logistics, interruptions, bureaucracy, at the end increase the costs in an as important as unforeseeable way.

$\checkmark$ The plants in Spain have nowadays very reasonable costs. Labor costs that can be the half than in central Europe. Important flexibility levels. High potential of outsourcing. Close suppliers with high levels of real just-in-time. Logistic and connecting infrastructures comparable with the French, German or Italian. Trade unions capable to understand the reality. Therefore, this are plants with future for who worries about the shareholders on long term. 


\section{Excellent environment}

Factors favoring the initiative

Spain is an important world car manufacturer, with production focused on models in segments with the greatest electrification potential.

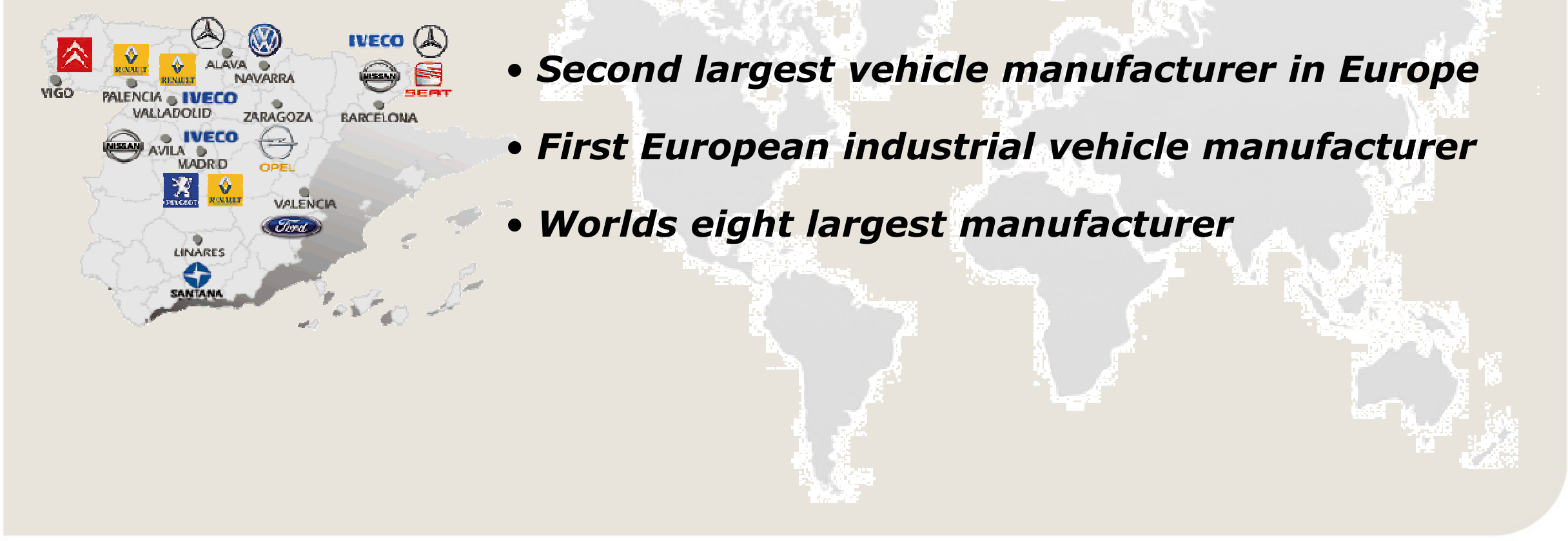




\section{Excellent environment}

Factors favoring the initiative

Spain has a large and competitive auto parts industry, with companies committed to $R \& D$ in projects related to electric vehicles
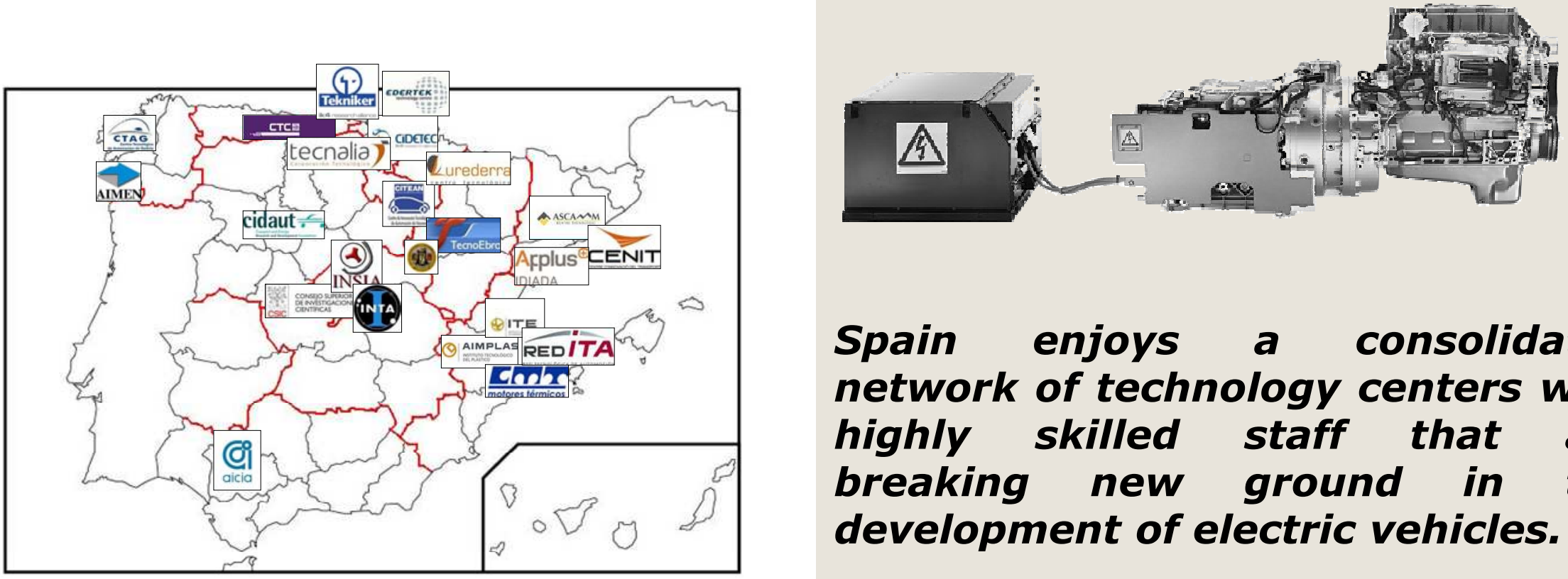

Spain enjoys a consolidated network of technology centers with highly skilled staff that are breaking new ground in the development of electric vehicles.

Research and development activities enjoy tax breaks 


\section{Excellent environment}

Factors favoring the initiative

In Spain there are 12 companies registered as manufacturers or distributers of batteries, but only two have manufacturing in Spain

The two main competitive advantages which present Spain refer to:

1.-The high weight and dangerousness of the batteries mean great logistic costs. That's why the proximity of the

\section{EXIDE}

Johnson Controls manufacturers is a fundamental competitive factor.

2.-A relevant factor in the development of the lithium batteries is the electronic of control of the batteries. The lithium batteries, specific for electric vehicles, require a complex electronic for its more effective use. 


\section{Excellent environment}

Factors favoring the initiative

Spain is located in the top five electricity producing countries of the European Union, making it one of the most attractive places for the development of electric vehicles.

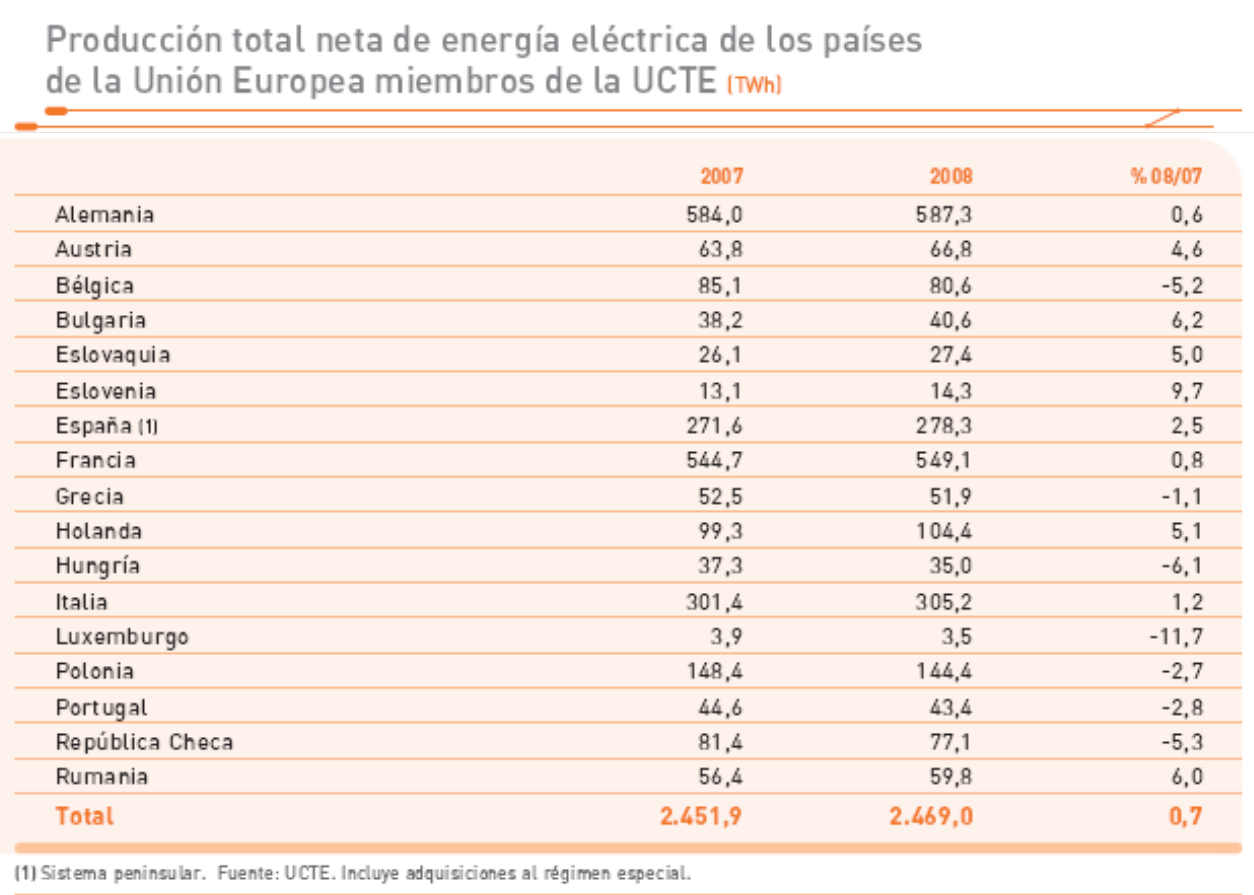




\section{Excellent environment}

Factors favoring the initiative

In addition, Spain offers lower energy transport costs than its competitors, as can be seen in the following graph.

Tarifas de transporte en países pertenecientes a ETSO $\left(^{*}\right]_{[\epsilon / \mathrm{MWh})}$

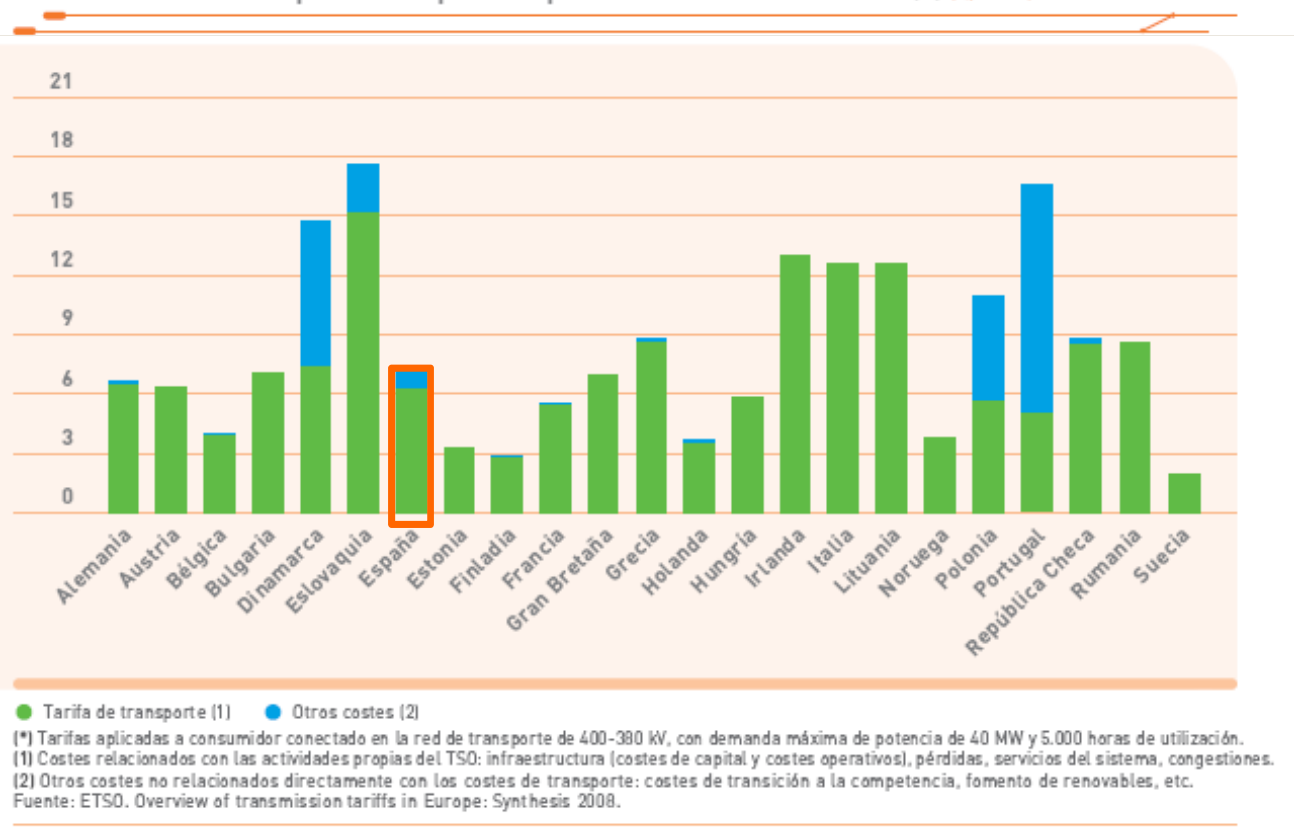




\section{Excellent environment}

Factors favoring the initiative

92.5\% of the increase in power output was provided mainly by renewable sources. Wind power meets $11 \%$ of the total demand.

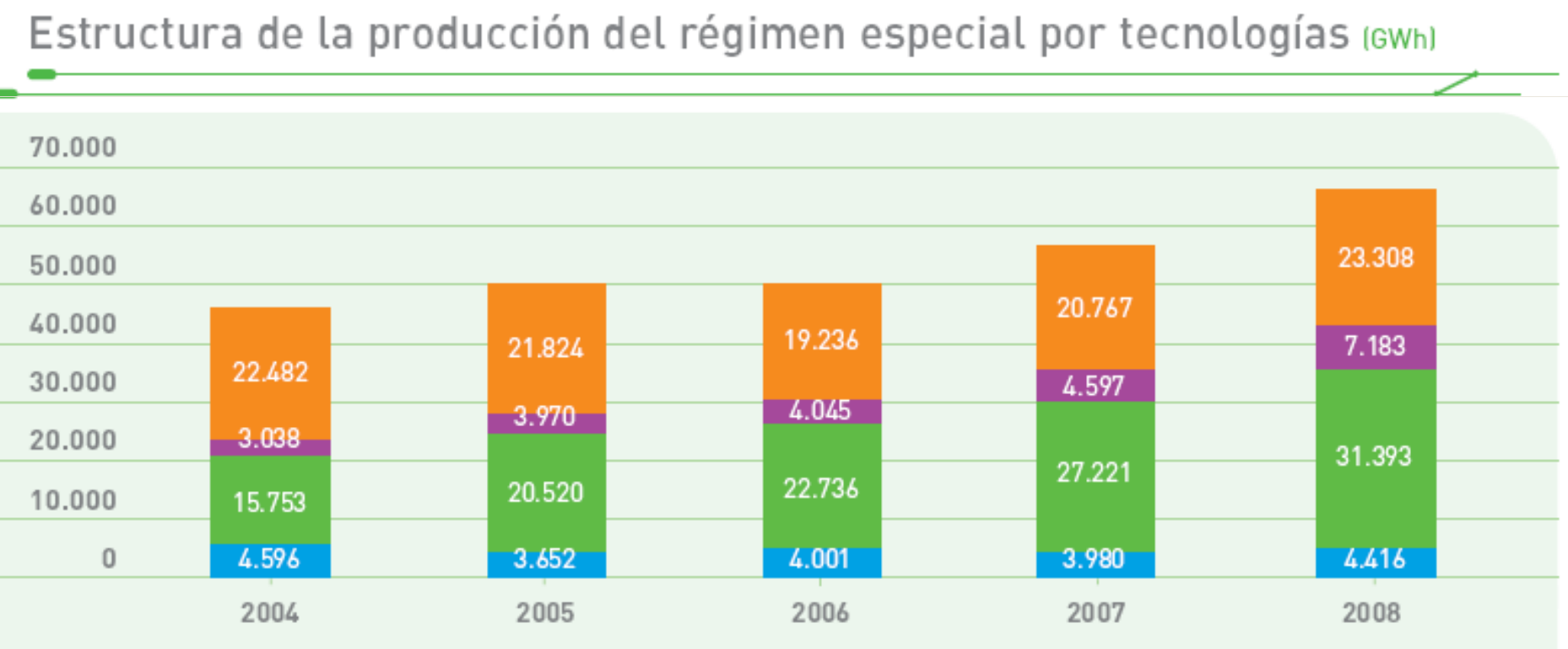

- Hidráulica

- Éblica

Otras renovables

- No renovables 


\section{Excellent environment}

Factors favoring the initiative

Main projects currently being developed in Spain
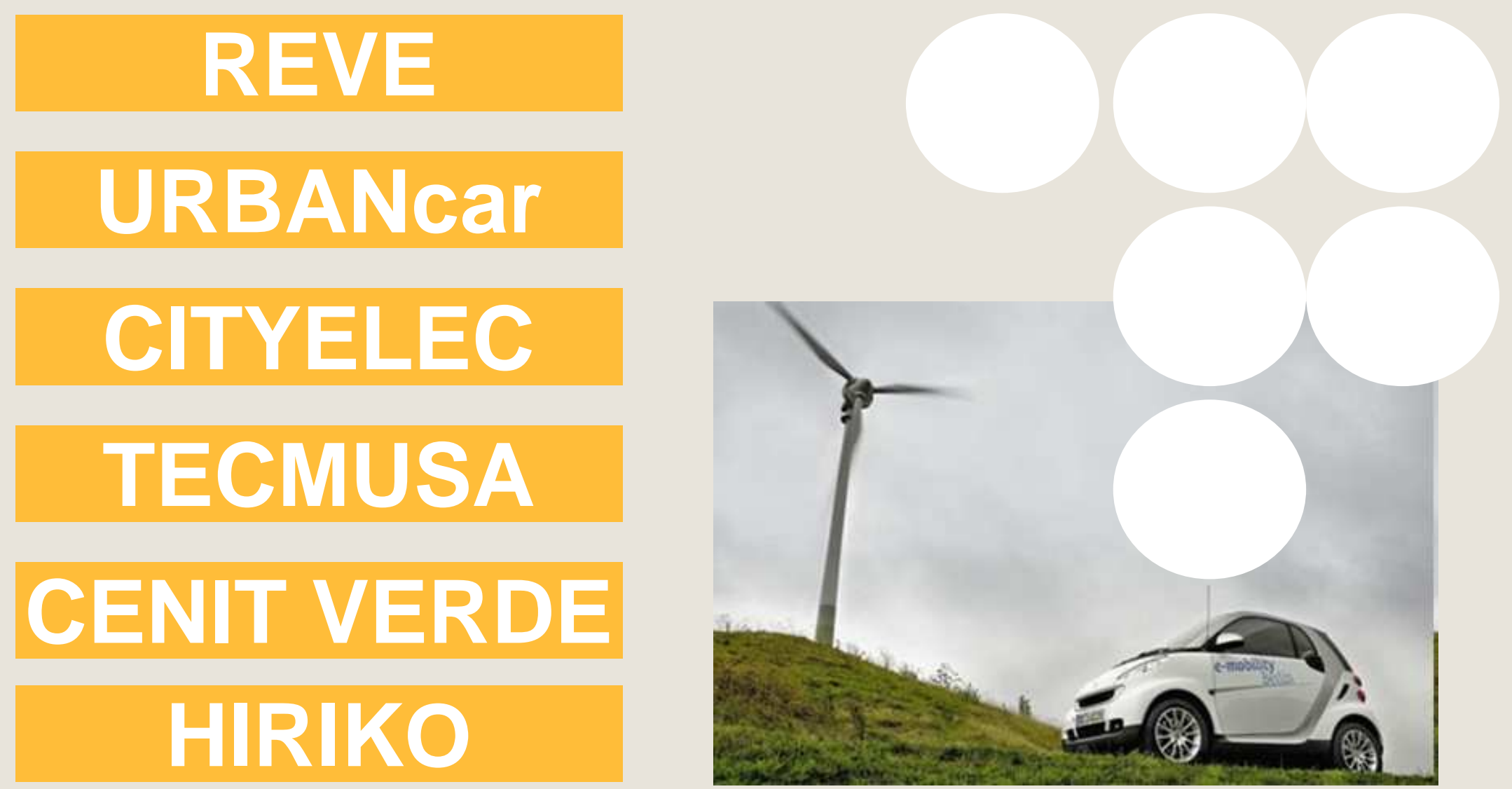


\section{Excellent environment}

\section{Project Hiriko}

Initiative promoted by AFYPAIDA, DENOKINN, EPSILON EUSKADI with the collaboration of the MIT for the development of a new solution for the new urban mobility as conceptualized under the "Citycar" concept. This corporate Project will transform the initial concept of the "Citycar" and turn it into an innovating industrial Project consisting of the development of the initial prototype and its industrialization by means of an innovating production and distribution model. This project is born with a clear vision of transforming and regenerating the industrial grid in both Alava and the Basque Country, and for this purpose it counts on the participation of companies from the automotive sector that are in charge of manufacturing and developing each one of the modules that compose the "Citycar" concept.

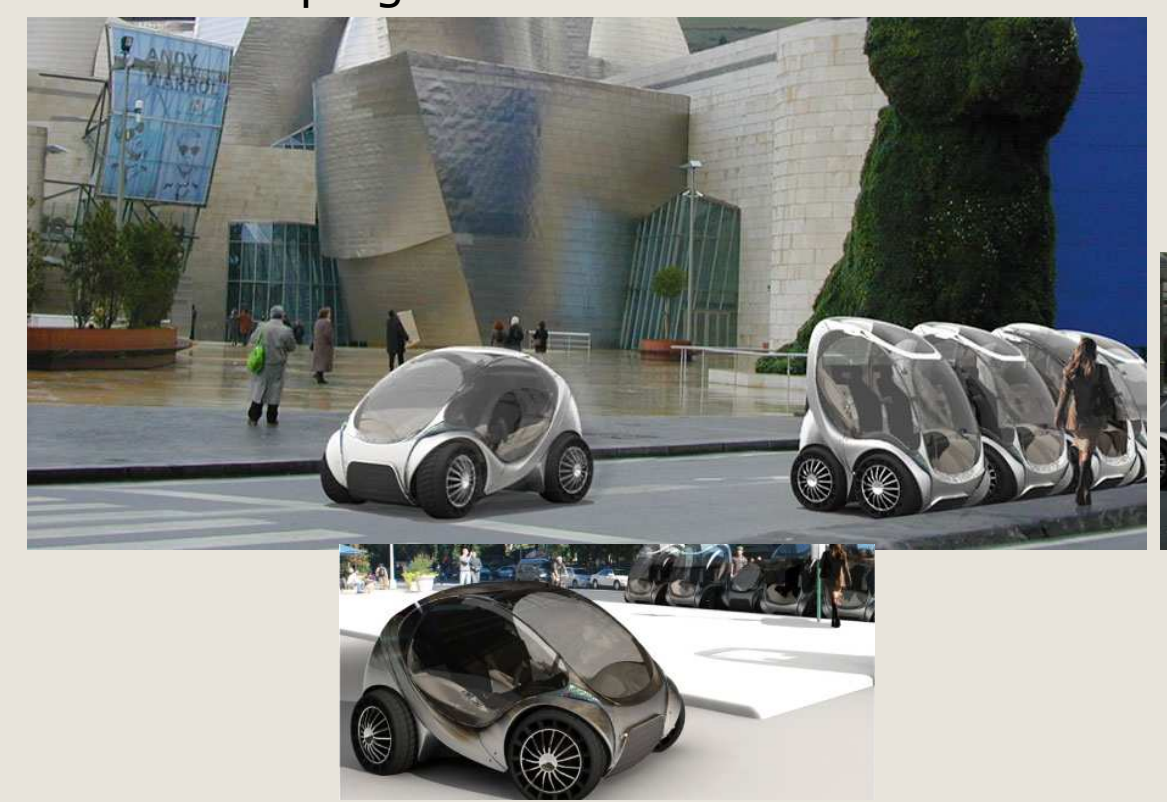

Launching in 2012. Price is estimated at 9.000€. It will be collapsible to facilitate parking, with a battery charging time of 12 minutes, $50 \mathrm{~km} / \mathrm{h}$ of maximum speed and $120 \mathrm{~km}$ of range.

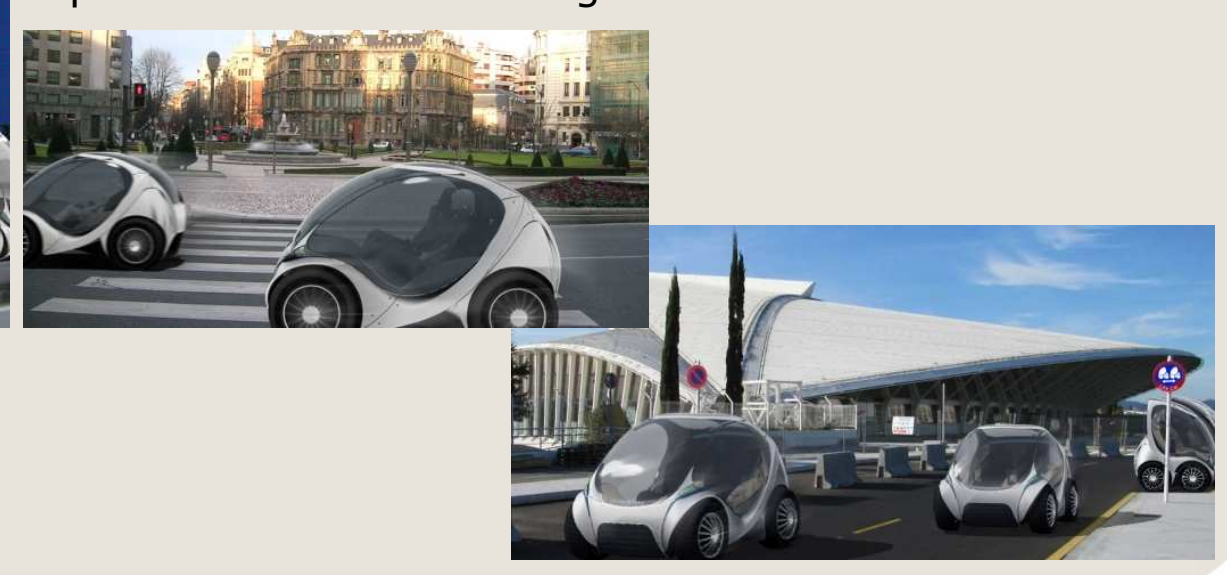




\section{Business Analysis}

\section{Current Business Situation in Spain}

Domestic and foreign manufacturers such as RENAULT, MERCEDES-BENZ, PEUGEOT, CITROËN, FORD and SEAT have already made firm decisions to produce electric powered vehicles in Spain.
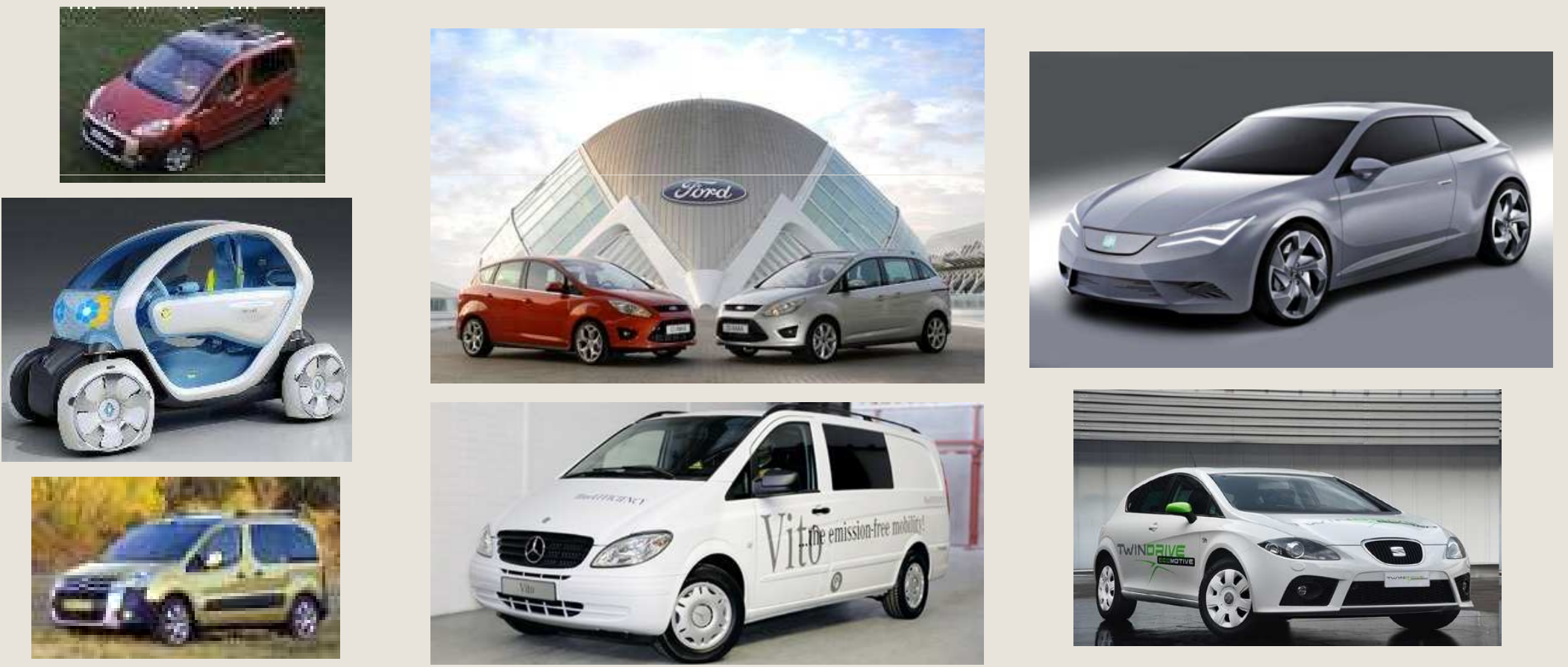

The main domestic and foreign parts companies with plants in Spain are already working on specific components and systems for electric and hybrid vehicles. 


\section{Business Analysis}

\section{Current Business Situation in Spain}

Based on imagination and research the bus Tempus has been conceived and built by Castrosua in collaboration with other companies, universities and technological centers. Tempus is an electric vehicle, able to run with zero pollutant emissions and low noise in those more sensitive areas of the city, with a range up to $300 \mathrm{~km}$.

With an electrically powered and diesel engine to help charge the batteries, this hybrid concept is an effective and ecological for city buses.
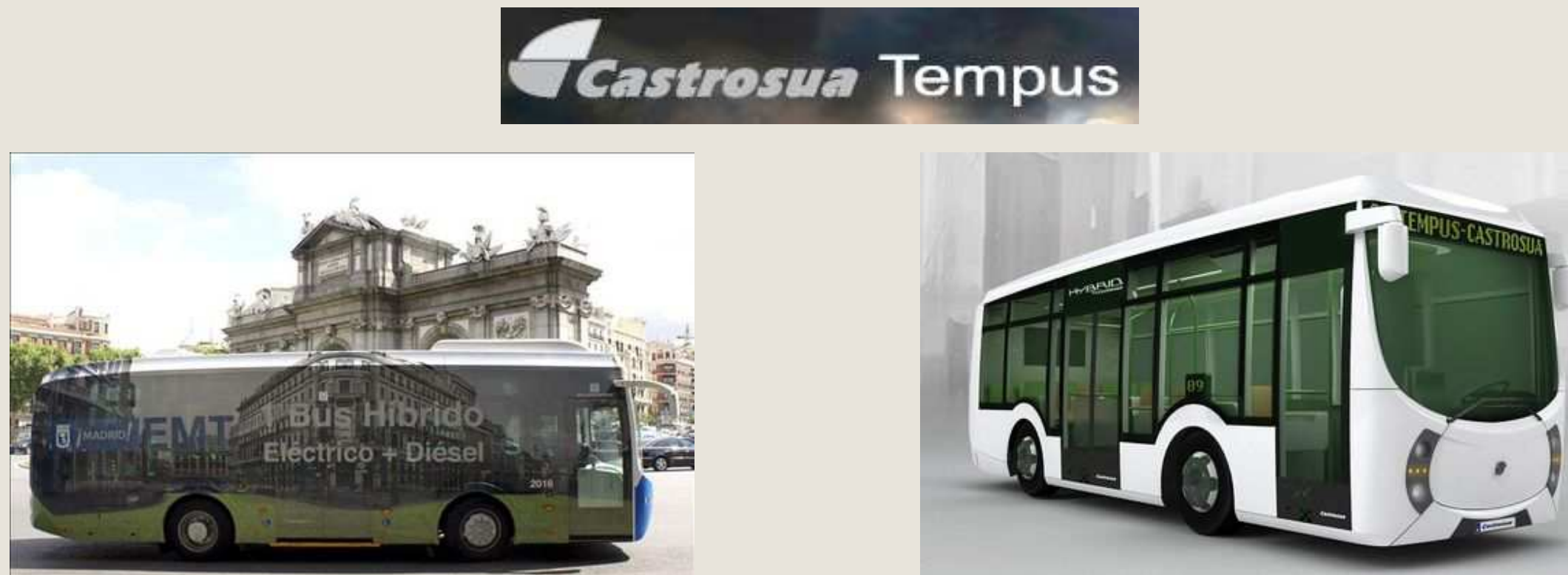


\section{Business Analysis}

\section{Current Business Situation in Spain}

The operator responsible for managing electricity in Spain, $R E E$, is considering and assessing the integration and development of electric vehicles in Spain.

In addition, large energy companies such as Cepsa, Repsol, Endesa, Iberdrola, Gas Natural and Acciona are taking part in projects to develop the necessary charging infrastructure for electric and plug-in hybrid vehicles. 


\section{Business Analysis}

\section{Progression Forecasts}

The electrification of the automobiles in use is a reality. In the next years the number of hybrid and electric vehicles will increase in a nearly exponential way.

\section{Ambitious target: 1 million hybrid and electric vehicles in 2014}

The consumer perception when purchasing a vehicle will change substantially towards values as energy efficiency and sustainability. That's why the prospects for the electric powered vehicles are very favorable. 


\section{Business Analysis}

\section{Interest in and purchase consideration of electric and hybrid vehicles}

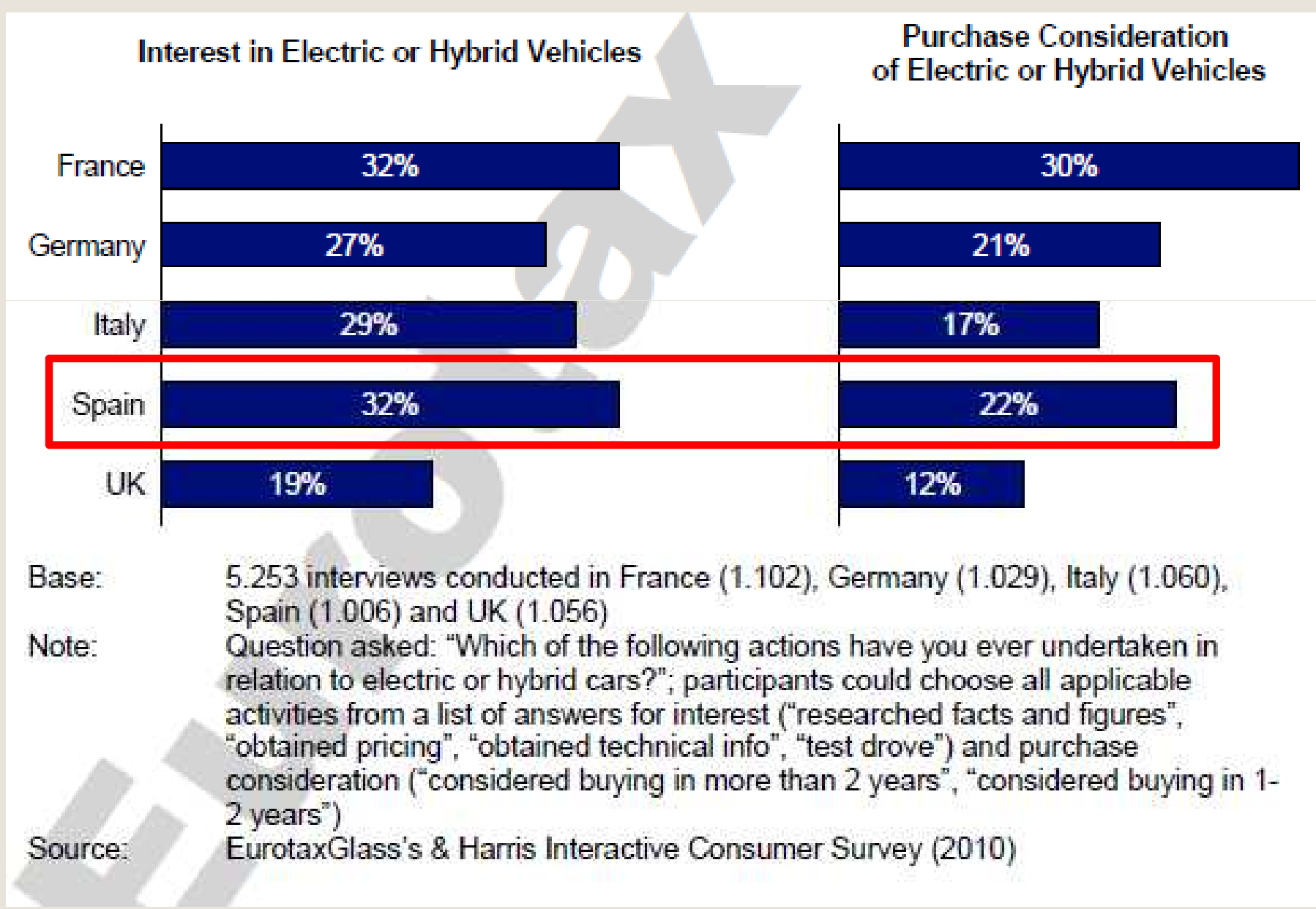




\section{Business Analysis}

\section{Purchase Intention of Electric and Hybrid Vehicles}

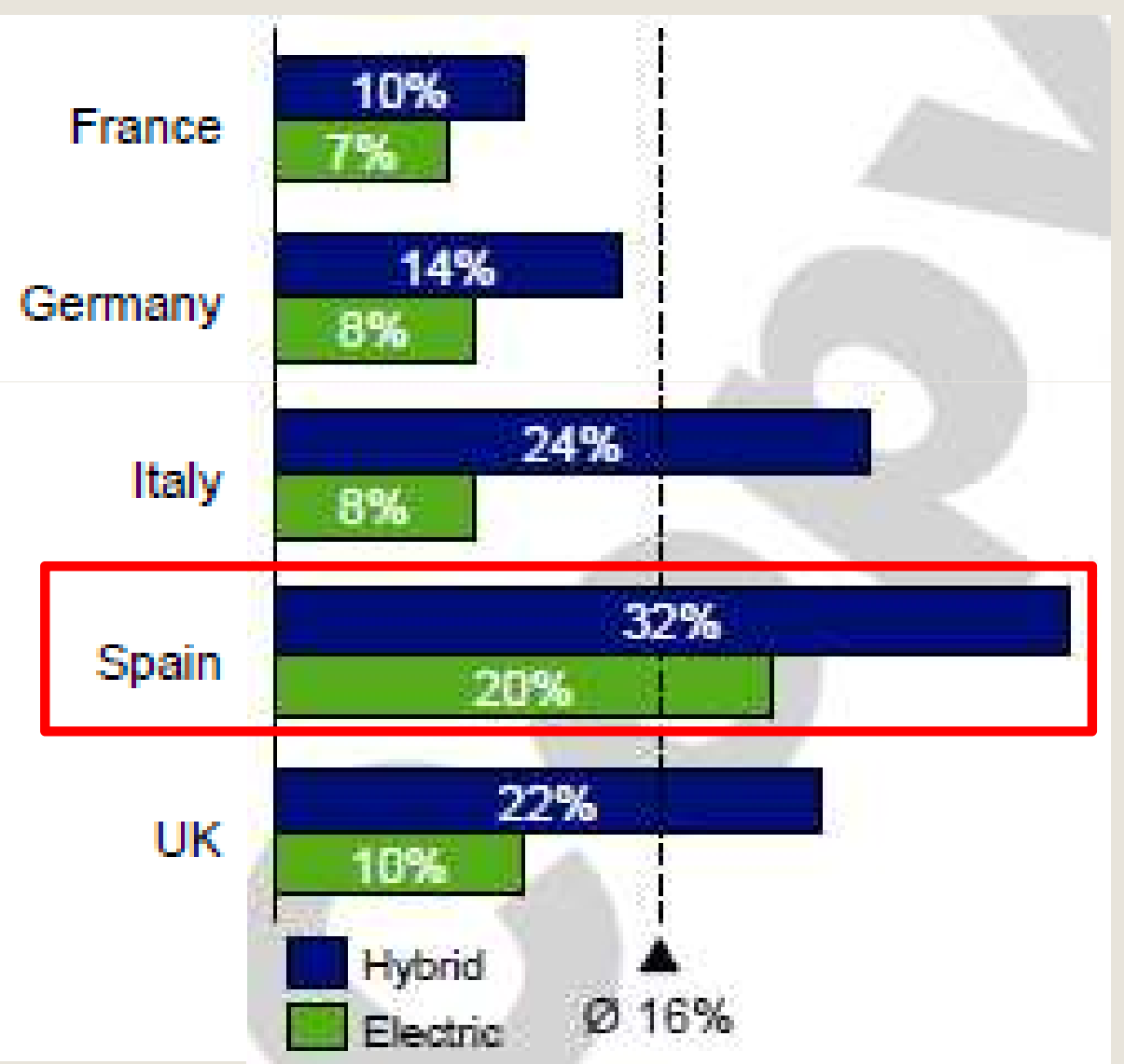

Source: EurotaxGlass's \& Harris Interactive Consumer Survey (2010) 


\section{Business Analysis}

\section{Progression Forecasts}

Spain is one of the European countries that is most committed to electric powered transport, both in the development of vehicles and supply infrastructure.

\section{IMPULSO DEL VEHICULO ELÉCTRICO EN ESPAÑA}

\begin{tabular}{|l|c|c|c|}
\hline Iniciativa & Objetivo & Al final de ... & \\
\hline $\begin{array}{l}\text { Corto Plazo: } \\
\text { MOVELE (1) }\end{array}$ & 2.000 & 2010 & \\
\hline $\begin{array}{l}\text { Medio Plazo: } \\
\text { EEIVE }{ }^{(2)}\end{array}$ & 250.000 & 2014 & \\
\hline $\begin{array}{l}\text { Largo Plazo: } \\
\text { Directiva EE.RR. }\end{array}$ & 2.500 .000 & 2020 & \\
\hline
\end{tabular}

(1) Proyecto Piloto gestionado por IDAE (casi $100 \%$ BEV).

(2) Estrategia Española de Impulso del VE (2010-2014)

(3) Directiva 2009/28/CE; Art. 3.4. Objetivo 2020: $10 \%$ de fuentes renovables en el transporte. (Biocombustibles y electricidad renovable en VE. - 38,5\% EERR en el mix eléctrico)

Legislación nacional: PANER (2011-2020): $342 \mathrm{ktep} / \mathrm{a}$ en 2020 (Consumo estimado - 20\% Full electric; 80\% PHEV; $12.500 \mathrm{~km} / \mathrm{a} ; 0,19 / 0,09 \mathrm{kWh} / \mathrm{km})$. 


\section{State aid}

\section{Incentives from the Ministry of Industry}

2011: Budget allocation for the implementation and development of the electric vehicle.

The budget stipulates a total of $\mathbf{8 1}$ million to subsidize de acquisition of electric vehicles.

Furthermore other actions are planned, as a support plan for the development and industrialization of the electric vehicle (70 million) and a support plan for the communication technologies between the electric grid and the electric vehicle (17,5 million).

Likewise a new line of guarantees of an amount of $\mathbf{5 0 0}$ million for the development and industrialization of the EV is planned. 


\section{State aid}

\section{Competitiveness Plan of the Automotive Sector}

Provision of financial support to the automobile sector specially for the development of projects concerning electric vehicles.

Designated to the realization of investments aimed at the manufacturing of more environmental friendly products.

Financing projects which consist of the production of green cars and car components which contribute to the realization of green cars and thereby significantly improve environmental protection.

\section{Call 2011: 215 million Euros}




\section{Integral Plan for the Electric Vehicle in Spain}

The quantitative target of the Integral Plan for the Electric Vehicle in Spain is to facilitate the introduction of electric and plug-in hybrid vehicles, to reach in 2014 the presence of 250.000 units of this kind of vehicles in Spain*.

To reach this target, the boost of the electric vehicle has to overcome the barriers on its introduction in the market, through four action lines or fields:

- Boost of demand and promotion of use of EV.

- Encourage its industrialization and the specific R\&D+I for the EV.

- Development of charging infrastructure and energy management.

- A group of horizontal measures which group aspects common to the before mentioned strategic lines, or which are not specific of one of them.

* This number of vehicles added to the number of hybrid vehicles reaches de total quantity of one million vehicles. 


\section{Integral Plan for the Electric Vehicle in Spain}

\section{Targets 2014:}

- new registrations of EV will reach 110.000 units (aprox 7\% of the market in 2008)

- 250.000 electric vehicles in use in Spain (1\% of vehicles in use 2008 ).

- 340.000 charging spots

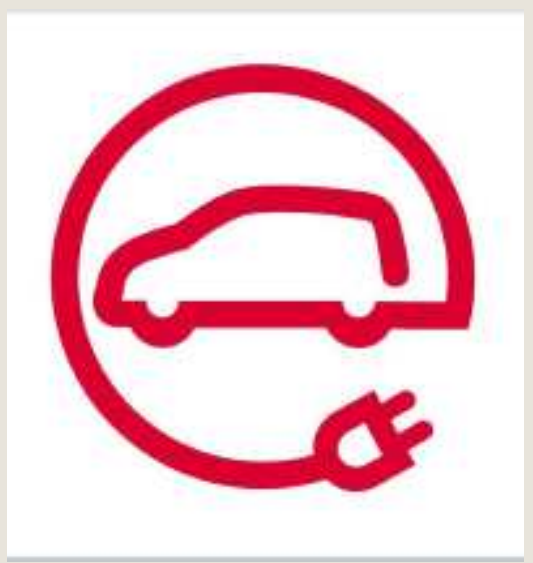




\section{Integral Plan for the Electric Vehicle in Spain}

\section{Public support of 590 million Euros in 2011-2012:}

- Incentive for acquisition: $25 \%$ of vehicle price (max. $6.000 €$ )

- Support for industrialization and $\mathbf{R} \boldsymbol{\& D + i}$. Inside the support to the strategic industrial sectors and to the reindustrialization the business plans focused on the electric vehicle will have priority. It is planned to assign 140 million Euros in 2011 y 2012.

- Support for the development of communication technologies between electric grid and electric vehicles. Through the Plan Avanza a line will enunciate to favor the development of technologies on communication systems for charging optimization. It is planned to assign $\mathbf{3 5}$ million Euros in two years.

- Priority lines of $\mathbf{R} \& \mathbf{D}+\mathbf{i}$ for electric vehicles. This initiative expects to identify and analyze the key technologies, and its spreading in business and research fields, as well as its fostering. For this the estimation is a contribution of $\mathbf{1 7 3}$ million Euros.

- Strategic Marketing and institutional communication. Identification of the barriers of habits and opinion which present the electric vehicle. Definition and realization of a marketing plan to overcome this barriers. In total the cost estimation of this actions is of $\mathbf{2}$ million Euros. 


\section{Proyecto Movele (IDAE)}

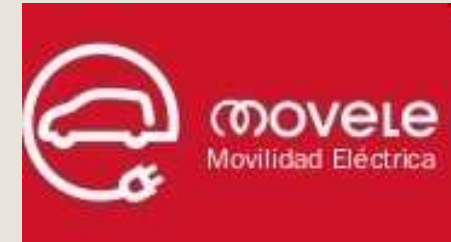

The Project Movele is an initiative meant to show the technical, economic and energy feasibility of electric vehicles through the introduction, in a timeframe of two years, of 2000 electric vehicles.

For this it counts with a total amount of 8 million $€$ for direct incentives between 750 and $20000 €$, depending on the type of vehicle, and which in case of cars can be up to $7000 €$.

In parallel, and to guarantee the logistic feasibility of this project, the city councils from Madrid, Barcelona and Seville will collaborate with the Government through the implementation and put in operation of a pilot network of public charging stations for electric vehicles. Specifically, and thanks to the agreements signed with this three big cities, 546 public charging spots will be installed -280 in Madrid, 191 in Barcelona and 75 in Seville- between 2009 and 2010. The investment associated to this infrastructures add up to 2.5 million $€$. 


\section{Spanish Electric Vehicle Forum (FORẼVE)}

The Spanish Forum of the Electric Vehicle (FORẼVE) starts with the target to boost the manufacturing, use and energy use of this mean of transport. FORẼVE is an private initiative promoted by FITSA (Foundation Technological Institute for the Safety of the Automobile) and by IDAE (Institute for the Diversification and Saving of Energy).

FORẼVE will concentrate on carrying out and promoting useful actions for the following fields:

$\checkmark$ The industry and the technology

$\checkmark$ Boost of the demand

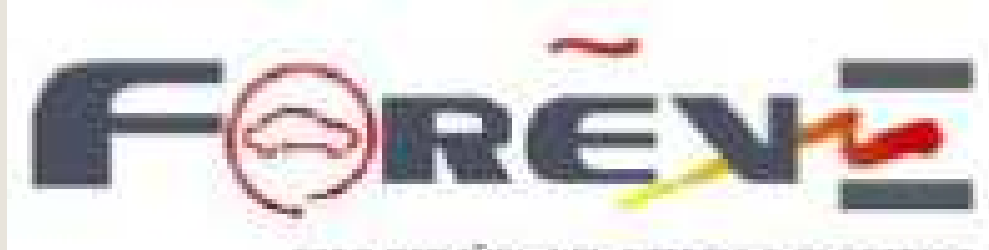

$\checkmark$ The technological solution for a sustainable mobility

$\checkmark$ The energy services required by the vehicle, as well as by the electric energy supply management.

$\checkmark$ Support services for the public initiatives that promote the use of electric vehicles. 


\section{Project CENIT VERDE}

The aim of the project is the research and development of technologies which allow a fast, economic and reliable market penetration of the plug-in hybrid and electric vehicles, manufactured mostly in Spain. It is structured in seven principal activities:

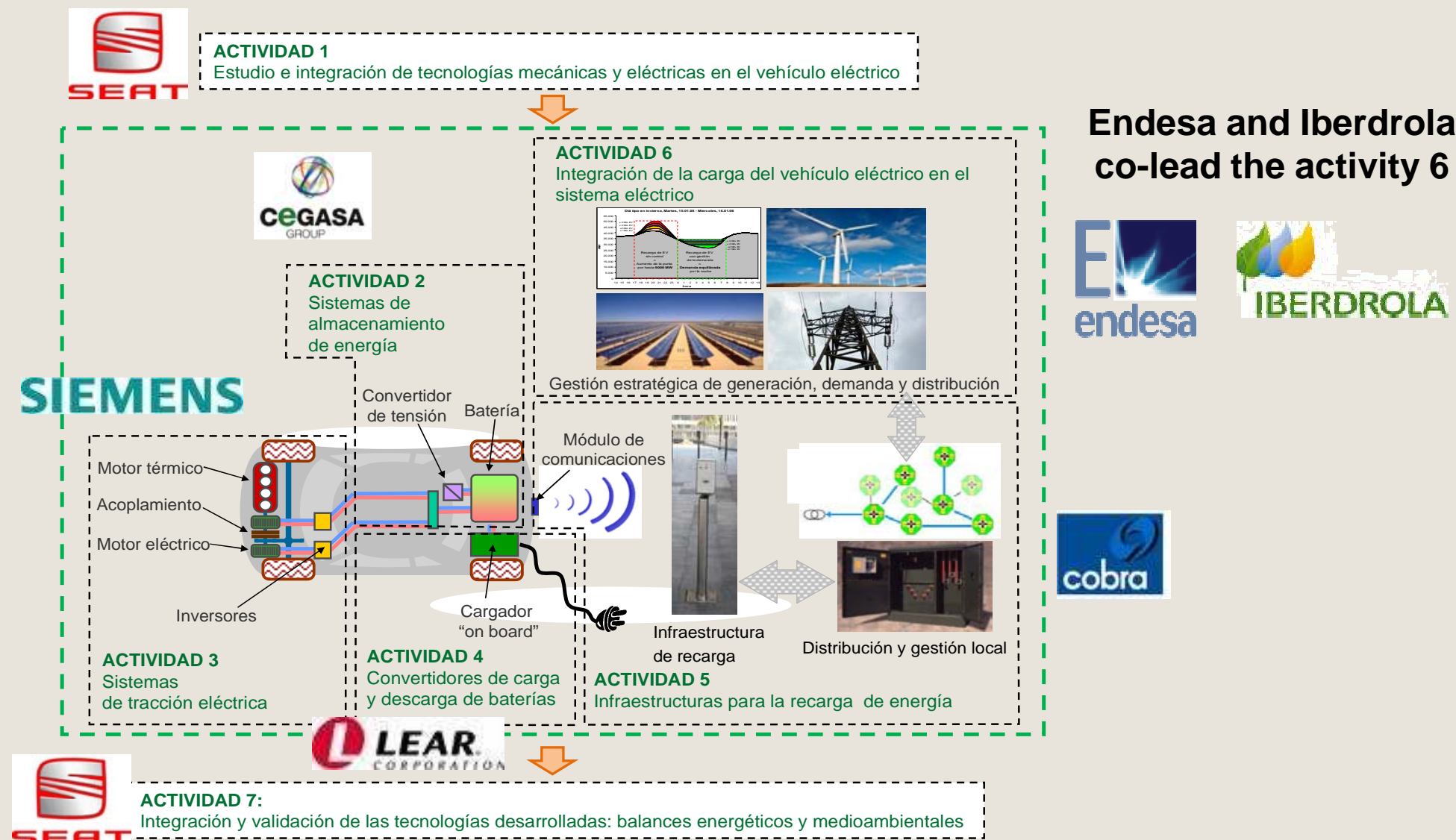

(1) Proyecto CENIT (Consorcios Estratégicos Nacionales en Investigación Técnica) dentro del Programa Ingenio 2010 del CDTI (Centro para el Desarrollo Tecnológico Industrial), dependiente del Ministerio de Ciencia e Innovación. Participantes: SEAT, CEGASA, SIEMENS, LEAR, COBRA, ENDESA, IBERDROLA Y REE. 


\section{Green eMotion (European Comission)}

\section{Green eMotion Initiative to prepare the mass market for electromobility in Europe}

The 42 partners in the initiative comprising industrial companies and automobile manufacturers, utilities, municipalities, universities, and technology \& research institutions are to input, exchange and expand their know-how and experience in selected regions within Europe:

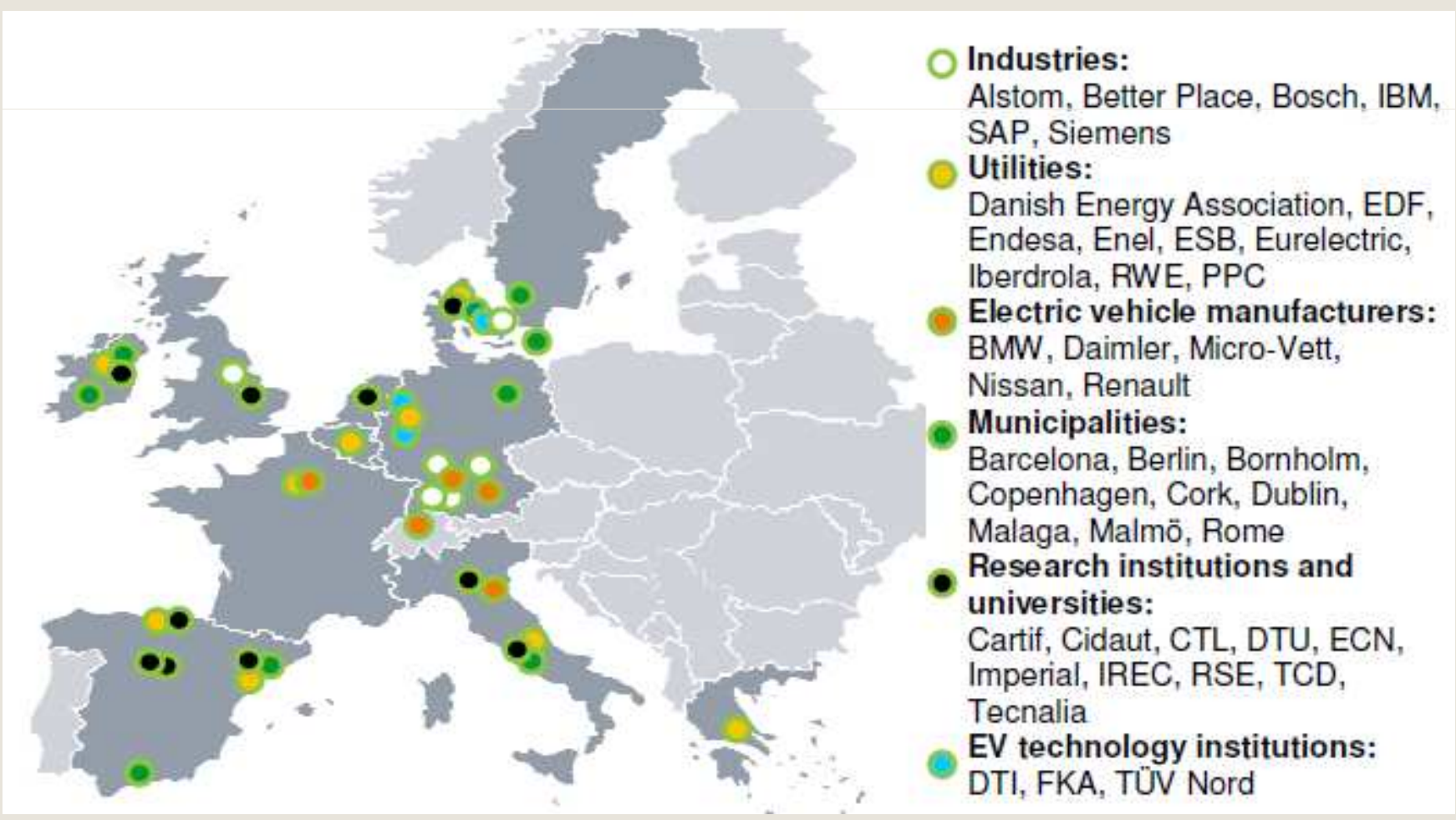




\section{Green eMotion (European Comission)}

\section{EU-wide demonstration features: Consumer label / EU clearing house / standards and} interoperability / cross-border rally

\section{Strasbourg}

Special features: Plug-in hybrid vehicles, cross border connection with Karlsruhe / Stuttgart

\section{Ireland (Dublin, Cork)} Special features: DC charging stations, $\mathrm{kWh}$ billing system, supplier choice

\section{Madrid}

Special features:

Advanced RES

integration studies, smart grid integration etc.

\section{Malaga}

Special features:

Embedment in smart city concept, V2G, B2G, DC charging stations
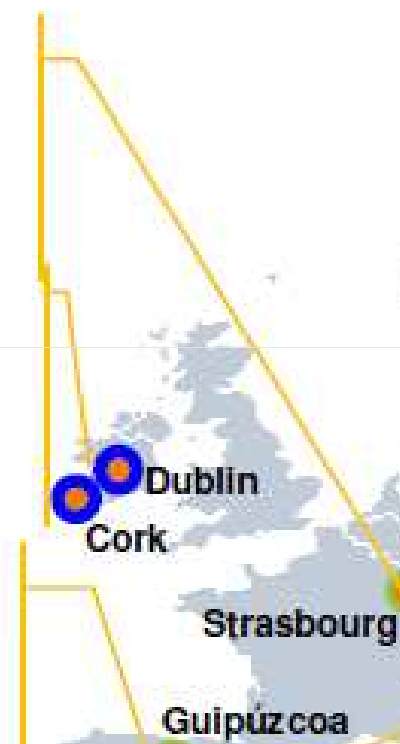

C Barcelona

\section{Madrid}

Malaga

\section{g}

Karlsruhe/Stuttgart

Special features: Smart Grid $\quad$ Copenhagen, Bornholm,

features, optimised bidirectional charging, crossborder connection with Strasbourg

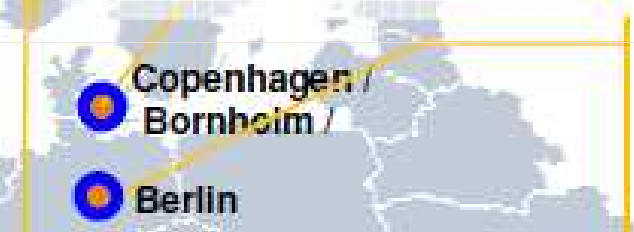

\section{Karlsruhe/Stuttgart}

\section{Budapest}

Pisa
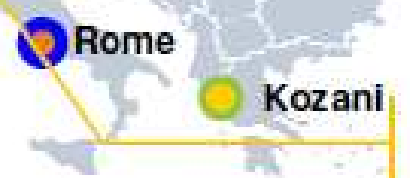

\section{Italy (Rome, Pisa)}

Special features: System approach enabling innovative services and user interfaces, $\mathrm{kWh}$ billing system, alternative business models testing 


\section{Cooperation and Leadership Opportunities}

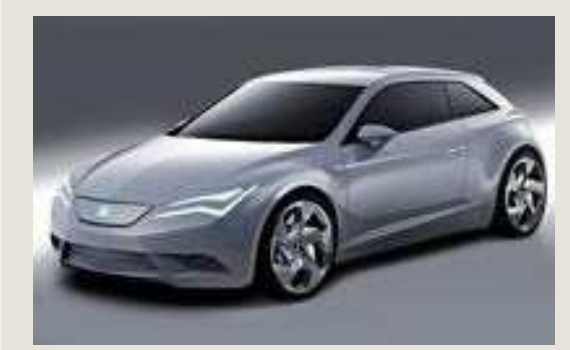

2009: Spain was the second European vehicle manufacturer

11 vehicle manufacturer in Spain

Opportunity of attraction of R\&D+I activities to Spain

Opportunity of cooperation and synergies with the big European automotive groups present in Spain.

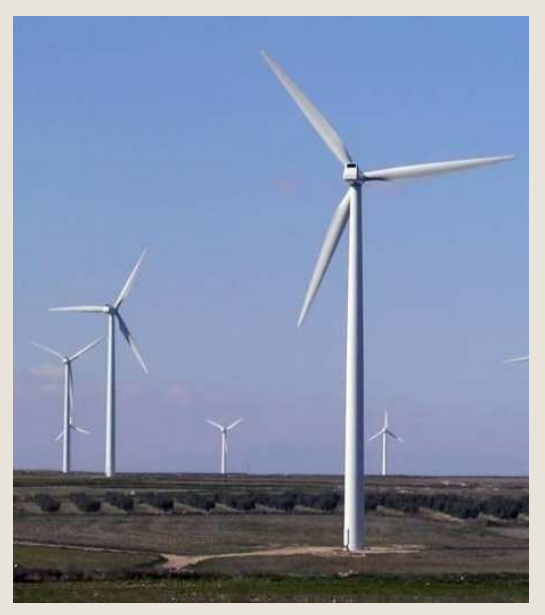

Spain: world leader country in renewable energies (TOP-5 in installed capacity and world leading companies)

$\square$ Spain must solve soon the problem of squander of the renewable energy in off-peak hours (night hours), being the EV an excellent opportunity.

$\square$ Capacity of Spanish leadership in technologies of integration and management of the demand.

$\square$ Spain has companies that are reference at international level on electronic measurement and tarification systems

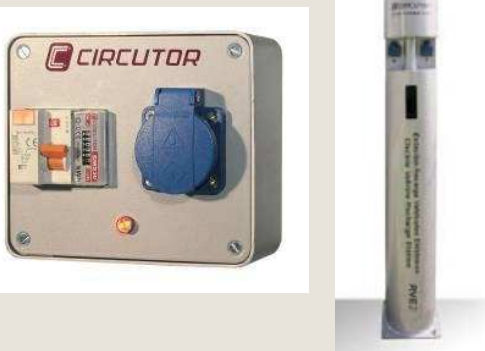

$\square$ In Spain there are companies with capacity for the development if the communications between vehicle and charging spot

$\square$ Spain counts with leading companies in infrastructure and civil works

$\square$ Leadership capacity in development and management of charging systems for EV 


\section{Conclusions}

The electric vehicle is a reality in Spain, currently there are projects for its development

Public administrations and private companies are boosting this initiative

Spain has outstanding competitive advantages, as the business infrastructure of very developed and specialized technological and industrial centers

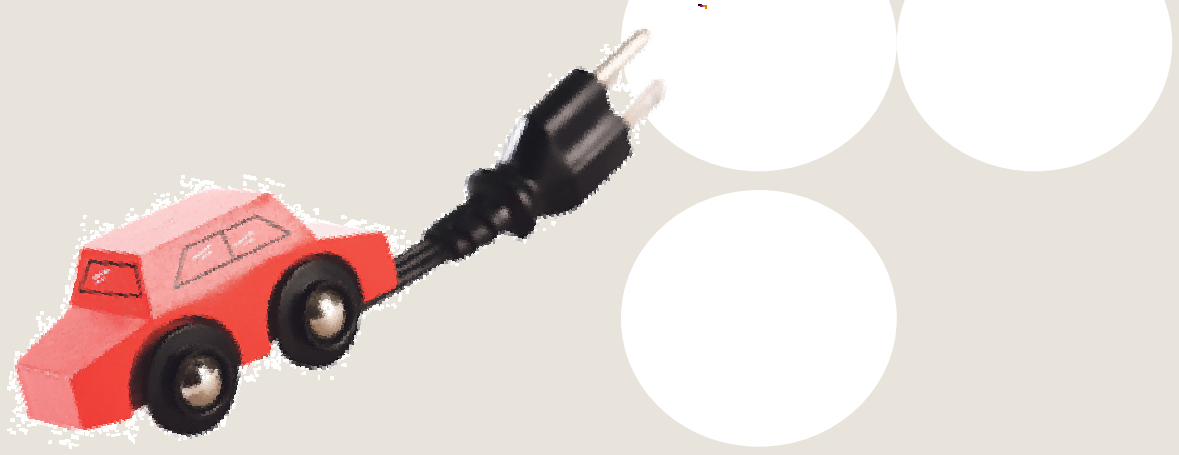




\section{SPAIN WILL HOST ELECTRIC VEHICLE SYMPOSIUM 2013}

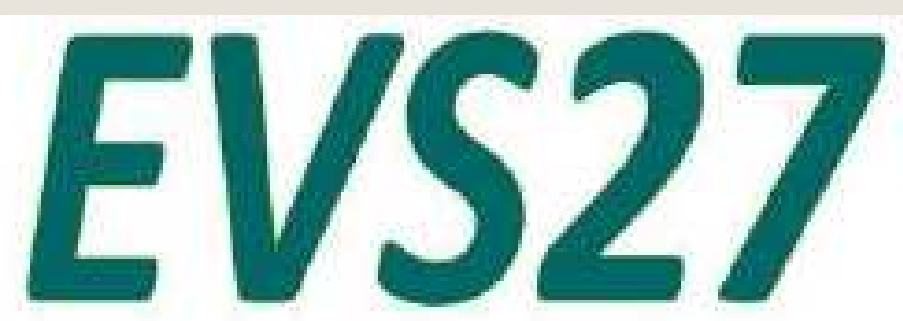

Barcelona 2013

Barcelona: voted to host EVS27, June 2013.

Preparation of Spanish candidacy was led by:

- Barcelona City Council

- IDAE: Institute for Energy Diversification and Saving (Ministery of Industry).

- AVELE: Spanish Association of EV 
Thank You Very Much 